\title{
PEREMPUAN DAN FILTER GLOBALISASI
}

\author{
Oleh: M. Jamil ${ }^{1}$
}

Secara eksistensial, setiap manusia mempunyai harkat dan martabat yang sama, sehingga secara asasi berhak untuk dihormati dan diperlakukan sesuai dengan harkat dan martabatnya (Trisakti Handayanirakat, 1996: 9). Begitu juga dengan keberadaan seorang perempuan. Menghormati dan diperlakukan dengan selayaknya merupakan suatu keharusan.

Perempuan bisa diartikan makhluk lemah lembut dan penuh limpahan kasih sayang, karena perasaan perempuan begitu halus nan mempesona. Dewasa ini, bila melihat sifat perempuan syarat akan keindahan, kelembutan serta rendah hati dan menjaga/memelihara. Seperti itulah sekilas gambaran perihal perempuan yang sering terdengar dewasa ini.

Bila dilihat secara biologis dari segi fisik, perempuan dibedakan atas perempuan lebih kecil dari laki-laki, suaranya lebih halus, perkembangan tubuh perempuan terjadi lebih dini, kekuatan perempuan tidak sekuat laki-laki dan sebagainya. Perempuan mempunyai sikap pembawaan yang kalem, perasaan perempuan lebih cepat menangis dan bahkan pingsan apabila menghadapi persoalan berat. (Murtadlo Muthahari, 1995: 107).

Akan tetapi, dibalik itu perempuan ibarat permata yang harus dijaga dan dihormati keberadaaannya, karena perempuan merupakan bagian yang terpenting dibalik kesuksesan seseorang, baik itu kesuksesan anak-anaknya, lebih-lebih kesuksesan suaminya. Semisal Ibu dalam hal mendidik anak, perempuan sangat besar perannya, karena perempuan yang jauh lebih lama membersamai anakanaknya dalam berumah tangga. Dengan peran yang begitu besar dalam hal mendidik anak tersebut, seorang perempuan dituntut untuk memperkaya

\footnotetext{
${ }^{1}$ Ketua Umum Pusat Studi Mahasiswa Pascasarjana (PUSMAJA) Mbojo-Yogyakarta Periode 2015-2017 | | Ketua II Bagian Eksternal Dewan Pimpinan Cabang Perhimpunan Mahasiswa Hukum Indonesia Daerah Istimewa Yogyakarta (DPC PERMAHI DIY) Periode 2012-2014 | Email: jamilncera@gmail.com | FB/Youtube/IG/Twitter: @MJAMILSH | Website: http://www.mjamil.my.id.
} 
pengetahuan dan pengalannya, serta perlu mendidik dirinya dilingkup strata pendidikan setinggi-tingginya.

Selain itu, Sri Lestari dalam Victorianus Aries Siswanto (2009: 72) mengatakan bahwa secara umum masih sedikit yang menyadari bahwa perempuan menghadapi persoalan yang spesifik gender, yaitu persoalan yang hanya muncul karena seseorang atau kelompok orang adalah perempuan. Tidak saja di kalangan laki-laki, tapi kaum perempuan sendiri yang masih banyak tidak menyadari hal tersebut, sehingga memandang tidak perlu persoalan perempuan harus dibahas dan diperhatikan secara khusus. Kondisi demikian terjadi karena mendalamnya penanaman nilai-nilai mengenai peran laki-laki dan perempuan, yang menganggap sudah kodratnya perempuan sebagai ratu rumah tangga, sebagai pengendali urusan domestik saja begitu dominan di masyarakat kita, sehingga adanya pikiran dan keinginan mengenai kesempatan beraktivitas di luar domain rumah tangga dianggap sesuatu yang mengada-ada, sehingga tidak aneh muncul paradigma perempuan tidak perlu sekolah tinggi toh akhirnya hanya akan mengurus sekitar kasur, sumur, dan dapur.

Seiring dengan kemajuan arus globalisasi, wanita sudah mulai menampakkan kemampuannya walaupun masih lebih rendah dibanding laki-laki, ditunjukkan oleh data BPS tahun 2000, wanita sekarang mulai terlihat memiliki motivasi untuk terjun dibidang wiraswasta atau usaha dengan alasan mengurangi pengangguran, menciptakan lapangan kerja. Sebenarnya sudah lama sebagian wanita Indonesia terlibat dalam wiraswasta namun karena adanya persoalan spesific gender, maka pemberdayaan wanita itu belum tersentuh dan belum nampak di bumi Indonesia ini (Victorianus Aries Siswanto, 2009: 72).

\section{Perempuan dan Keharusan Memfilterisasi Arus Globalisasi}

Globalisasi merupakan proses integrasi internasional yang terjadi karena pertukaran pandangan dunia, produk, pemikiran, dan aspek-aspek kebudayaan lainnya. Seorang pakar Indonesia, Selo Soemardjan memandang globalisasi sebagai sebuah proses terbentuknya sistem organisasi dan komunikasi antar 
masyarakat di seluruh dunia untuk mengikuti sistem dan kaidah-kaidah tertentu yang sama.

Dewasa ini, adanya globalisasi dapat dengan mudah kita dapatkan informasi, pandangan-pandangan, serta pemikiran yang berkembang di dunia internasioal. Selain itu, produk serta aspek-aspek kebudayaan yang terjadi di dunia interasioanal dapat dengan mudah masuk dan dinikmati di Indonesia. Adanya arus globalisasi mampu dengan mudah merubah pola pikir (mind set) manusia, baik pada pola pikir yang negati, lebih-lebih pola pikir yang positif. Hal demikian, juga tidak terkecuali pada perubahan pola pikir perempuan, karena globalisasi selalu menawarkan yang baru dan yang indah-indah.

Seorang perempuan mudah dibujuk dan dirayu dengan hal-hal indah dan menggiurkan. Dengan hadirnya era globalisasi dewasa ini seorang perempuan dituntut dan diharuskan untuk membentengi dirinya dari rayuan-rayuan menggiurkan akibat era globalisasi. Saat ini banyak hal mudah didapatkan informasinya, semisal dalam hal informasi fashion-fashion yang lagi trend di dunia, dengan mudah bisa didapatkan di dunia digitalisasi saat ini. Apalagi saat ini Negara Republik Indonesia sudah dijangkiti era perdagangan bebas. Bukan hanya barang elektronik, teknologi bahkan budaya pun bebas masuk di negara tercinta kita Indonesia. Sehingga tidak jarang dari remaja Indonesia terlebih khusus perempuan yang lebih tertarik dengan barang-barang bahkan budaya dari luar yang jelas-jelas tidak seutuhnya sesuai dengan adat istiadat dan jati diri bangsa Indonesia tercinta. Dengan kondisi demikian, apakah kita sebagai anak bangsa hanya berdiam diri dan menerima begitu saja apa pun budaya barat tanpa menyaring serta memfilterisasi mana yang sesuai dengan karakteristik bangsa kita tercinta? Itu yang perlu kita harus jawab bersama agar tidak jadi macan ompong di bangsa sendiri. Oleh karena itu, perempuan Indonesia apabila dihadapkan dengan kondisi demikian harus memfilterisasi arus globalisasi yang mengancam tersebut.

Perempuan Indonesia, harus bahu membahu untuk ambil bagian dalam berkontribusi nyata dalam menjanggal arus globalisasi dewasa ini, dalam pribadi seorang perempuan, harus menumbuhkembangkan semangat nasionalisme yang tinggi serta tangguh pada pribadinya. Misalnya dalam hal fashion, sebagai 
perempuan Indonesia harus mempunyai semangat menularkan rasa mencintai produk dan hasil karya dalam negeri. Kalau kita cermati dan telusuri lebih mendalam, hasil karya anak bangsa juga yang lebih unggul yang dapat kita banggakan daripada mendewakan produk-produk asing.

Saat dihadapkan dengan kondisi yang baru, maka yang harus dilakukan seorang perempuan adalah mempelajari terlebih dahulu budaya atau teknologi yang dimaksud. Mana-mana yang sesuai dengan karakteristik bangsa kita dan mana yang tidak. Karena perempuan yang cerdas, dia dapat memilah tanpa harus menerima dengan bulat apa informasi yang ia dapat.

Perempuan Indonesia harus mampu memikirkan apa dampak negatif dan positif dari budaya atau teknologi dewasa ini. Karena pada dasarnya, setiap budaya serta teknologi yang masuk, pasti mempunyai dampak positif dan negatif. Untuk perempuan tangguh Indonesia, sebaiknya pilih budaya atau teknologi yang lebih banyak membawa manfaat bagi diri sendiri dan orang lain disekelilingnya.

Selain menghindari dampak negatif arus globalisasi, perempuan Indonesia juga tidak boleh menafikkan adanya dampak positif globalisasi. Beberapa hal positif yang bisa dipelajari diantaranya, terkait adanya etos kerja dan disiplin yang tinggi, serta kemajuan Iptek dari negara lain.

\section{Perempuan Perlu Membangun Kualitas Diri}

Dewasa ini manusia dihadapkan dengan situasi serba canggih, kompetisi yang super kuat. Upaya sebagai pembendung kondisi demikian perlu kesadaran dan kemauan penuh dalam diri setiap insan untuk sadar dalam melakukan penguatan diri. Upaya seperti yang tergambar diatas tidak hanya berlaku untuk laki-laki, pun demikian berlaku juga untuk perempuan.

Banyak persoalan-persoalan yang membendung sebagai penghalang pengembangan potensi diri seorang perempuan. Rosida Tiurma Manurung (2012: 97) mengungkapkan bahwasannya masalah kualitas diri perempuan antara lain dipengaruhi lingkungan di mana perempuan tersebut dibesarkan. Seperti kondisi sosial budaya, pandangan masyarakat, sangat berpengaruh terhadap perkembangan diri seseorang, tidak terkecuali seorang perempuan. Selain itu, 
yang tidak kalah penting adalah kesadaran sikap dan kesadaran perempuan itu sendiri untuk belajar mengenali diri sendiri, serta memahami sesuatu yang menjadi cita-cita, berdasarkan kemampuan dan potensi yang dimilikinya.

Membangun sebuah keyakinan dan mengungkapkan dengan sejujurnya suatu keinginan sangat perlu dilakukan, karena tidak semua hal mampu terbaca oleh semua orang tentang apa dan bagaimana keinginan seseoang, terlebih keinginan untuk memimpin suatu organisasi atau suatu pemerintahan. Hal ini berlaku bagi semua orang, tidak hanya berlaku bagi seorang laki-laki, lebih-lebih ini harus dilakukan oleh seorang perempuan. Hilangkan semua keraguan dalam hati untuk mau mengambil peran strategis bila mempunyai keyakinan kuat dan mempunyai misi yang besar untuk membawa organisasi atau pemerintahan agar lebih besar dan lebih berjaya lagi. Dalam hal ini, Rosida Tiurma Manurung (2012: 97) mengungkapkan bahwa perempuan sebaiknya harus jujur terhadap kemauannya untuk menduduki posisi pemimpin, dan sewajibnya disertai niat dan tekad yang kuat untuk maju dan berkembang menuju peningkatan kualitas diri. Hal ini mesti dilakukan karena tidak sedikit perempuan yang sebenarnya memiliki potensi untuk berkembang, tetapi ragu-ragu dan takut mengambil risiko sehingga lebih suka menangguhkan pekerjaannya. Tidak mungkin seorang perempuan menduduki posisi pemimpin jika ia tidak membangun kualitas dirinya. Upaya pemberdayaan potensi dan peningkatan kualitas diri seorang perempuan mutlak diperlukan untuk dijadikan sebuah kekuatan.

\section{REFERENCES}

Trisakti Handayanirakat, 1996, Memperjuangkan Hak Asasi Perempuan, dalam

Suara Wanita, Pusat Studi Wanita dan Kemasyarakatan, Universitas Muhammadiyah Malang.

Murtadlo Muthahari, 1995, Hak-hak Wanita dalam Islam, Lentera, Jakarta.

Victorianus Aries Siswanto, 2009, "Studi Peran Perempuan dalam Pengembangan

Usaha Kecil Menengah Melalui Teknologi Informasi di Kota Pekalongan”, Jurnal Dinamika Informatika, Volume I, Nomor 1, Maret 2009. 
"Perempuan dan Filter Globalisasi"

Rosida Tiurma Manurung, 2012, "Pembangunan Intelektualitas dan Kualitas Diri Perempuan sebagai Kekuatan untuk Menjadi Pemimpin dalam Era Globalisasi”, Jurnal Jenit, Volume 1, Nomor 2, 2012.

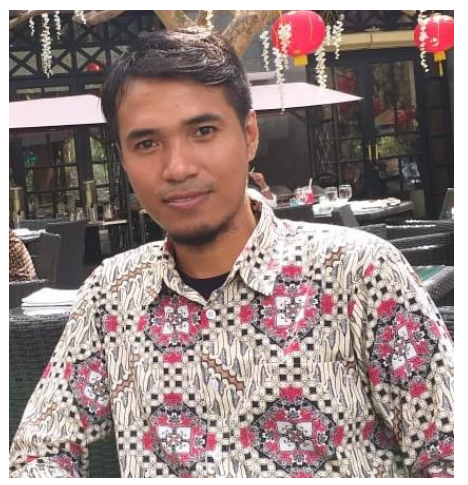

Penulis: M. Jamil, S.H.

Ketua Umum Pusat Studi Mahasiswa Pascasarjana (PUSMAJA) Mbojo-Yogyakarta Periode 2015-2017 | Ketua II Bagian Eksternal Dewan Pimpinan Cabang Perhimpunan Mahasiswa Hukum Indonesia Daerah Istimewa Yogyakarta (DPC PERMAHI DIY) Periode 2012-2014

\section{Ful Sumber Tulisan:}

M. Jamil, "Perempuan dan Filter Globalisasi", Majalah NUSANTARA IKPMDIYogyakarta, diterbitkan melalui Dinas Pendidikan Pemuda dan Olahraga (Disdikpora) Daerah Istimewa Yogyakarta, edisi Maret-April 2017, lihat Halaman 16-18. 